\title{
Nutrition and climatic stress in farm animals
}

\author{
By K. L. Blaxter, Nutrition Department, Hannah Dairy Research Institute, Kirkhill, \\ Ayr
}

Discussing the general principles which govern the distribution of domesticated livestock throughout the world, Wright (1954) distinguished between direct and indirect environmental stresses. Direct stresses result from temperature, solar radiation, humidity, rainfall and wind velocity. Indirect stresses comprise those which affect the supply and availability of food, and are determined by climatic and other factors which affect the growth of the plants that animals eat.

This distinction, made in many ecological studies (Hammond, 1947; Allee, Emerson, Park, Park \& Schmidt, I949), is equally applicable to nutrition. Adverse environments can increase the nutritional requirements of animals directly, or they may reduce the supply and quality of the food. Livestock production in adverse environments can be limited far more by these indirect effects than by an inability of the stock to maintain homeostatic equilibrium, which may best be illustrated by livestock husbandry in two very adverse environments. In arid deserts long droughts lead to lack of food. A typical people living there, the camel-breeding Rwala Bedouins, are nomadic, and their movements are dictated by the food and water supplies available for their stock (Wulsin, I949). In the extreme north of Europe the tundra can support plant growth for but a short time each year. Again livestock husbandry is nomadic, the Laplanders, for instance, moving their reindeer herds south with the approach of the long winter (Forde, 1946). In neither instance do the domesticated animals fail to maintain thermal equilibrium when food is available.

Even in temperate climates the indirect climatic stress appears to be paramount. Thus in Britain summer droughts accompanied by high air temperatures invariably lead to a reduction in pasture growth which appears to be the major cause of diminished production of milk in summer. It is unlikely that direct climatic stress is important, since experiments in which cows were continuously exposed to particular temperatures (Worstell \& Brody, I953) showed that milk production did not decline until air temperatures of $82^{\circ} \mathrm{F}$. were reached. It is improbable that even under the hottest conditions in the south of England temperatures would be above $85^{\circ} \mathrm{F}$. for long. Night temperatures would surely be below $85^{\circ} \mathrm{F}$. and, in view of the large heat capacity of the cow, i.e. the 'body mass thermal equilibration' of Herrington (I954), short day-time exposures to temperatures above $85^{\circ} \mathrm{F}$. could hardly be responsible for the summer fall in milk production.

During winter in Britain plant growth virtually ceases, and sheep have to fend on foggage and cattle have to be given conserved food. The fact that winter milk yields are in general lower than summer yields reflects not so much a direct stress of winter climate on cattle but an indirect one affecting their food supply. Sanders's (1927, 1949) studies of milk production in Britain and more recent studies by Burt 
(1954-5) on climatic and managerial influences on herd yields may be interpreted similarly. Plant breeders are now endeavouring to produce species of grass and fodder crops that can extend the grazing season in spring and autumn. This approach constitutes a direct attack on the indirect climatic stress to which cattle and sheep are exposed.

These examples show that livestock production in Britain is influenced far more by indirect than by direct climatic effects. Nonetheless, there is evidence that even in our temperate climate the environment influences the food requirements and performance of livestock.

Housing provides animals with a 'subclimate' during the winter. Even so, housed pigs grow less well in winter in Scotland than they do in summer (Kirkwood \& Smart, 1950) which suggests that the subclimate provided is not optimal. In Britain, housing has probably developed more to make the feeding and care of stock convenient than to provide them with an optimal physical environment and, of course, the loss caused by a failure to provide optimal conditions as well as the capital cost of providing them are important considerations.

The preceding paper (Findlay, 1958) dealt with the physiological effects of high environmental temperatures on cattle. The observations of major nutritional significance were that with cattle appetite for food is reduced at high temperatures. We have shown with sheep given constant food that high temperature results in increased heat production and hence a reduction in energy retention (Graham, Wainman, Blaxter \& Armstrong, 1958). The direct stress of heat certainly has marked nutritional effects. The discussion which follows deals mainly with the direct effects of cold on the animal's requirement for calories and other nutrients.

\section{The critical temperature of animals}

Energy requirements in cold environments depend on the critical temperature of the animal and the increase in its heat loss which occurs below this temperature. Rubner (I902) showed that the heat loss of animals in environments colder than their critical temperature was determined by physical laws. Scholander and his collaborators (Scholander, Walters, Hock \& Irving, 1950; Scholander, Hock, Walters, Johnson \& Irving, I950; Scholander, Hock, Walters \& Irving, 1950) confirmed this work with a variety of tropical and arctic mammals and birds and introduced a simple 'thermostat' analogy to explain the behaviour of different species of animals under cold conditions. Expressed mathematically, it is:

$$
\mathrm{T}_{\mathrm{C}}=40-\frac{\mathrm{H}}{\mathrm{K}}
$$

where $\mathrm{T}_{\mathrm{C}}=$ critical temperature $\left({ }^{\circ} \mathrm{C}\right.$. $), \mathrm{H}==$ normal level of heat production of the animal per $\mathrm{m}^{2}$ body surface, $\mathrm{K}=-\frac{\mathrm{dH}}{\mathrm{dT}}=$ heat conductance, or the change in the sensible heat $\operatorname{loss} / \mathrm{m}^{2}$ body surface with environmental temperature below the critical, and $40=$ assumed constant body temperature $\left({ }^{\circ} \mathrm{C}\right.$.). The heat conductance in this equation is the reciprocal of the 'total insulation' of Burton \& Edholm 
(1955). The amount of subcutaneous fat and of coat covering are the important factors influencing the magnitude of this measurement (Hammel, 1955; Herrington, I95I; Scholander, Walters et al, I950).

Our approach (Blaxter, Graham, Wainman \& Armstrong, I958; Blaxter, Graham $\&$ Wainman, 1958) to this problem has been similar to that of Scholander and follows that of Burton (1934). Our studies indicate, however, that the sheep does not maintain a rigidly constant body temperature irrespective of its environment, but that it can establish homeothermy at any rectal temperatures within the range of $3^{8-40^{\circ}}$. The sheep has, in other words, a considerable heat capacity, as indeed have many arctic mammals and birds which are termed by Irving \& Krog (1954) 'heterothermic' as distinct from poikilothermic. Furthermore, not the whole of the heat produced by an animal is available to keep it warm. Some heat is lost by a minimal vaporization from skin and respiratory passages. In sheep it amounts to about $300 \mathrm{Cal} . / \mathrm{m}^{2}$ body surface $/ 24 \mathrm{~h}$, a value similar to that in man (Winslow, Herrington \& Gagge, 1937). Heat is also lost when ingested food and water are warmed to body temperature. For example, a cow eating $100 \mathrm{lb}$. kale at a temperature of $0^{\circ}$ uses $40-50 \mathrm{Cal} . / \mathrm{m}^{2}$ to warm it, and in sheep this heat of warming can amount to more than $100 \mathrm{Cal} . / \mathrm{m}^{2} / 24 \mathrm{~h}$. It is heat which leaves the body by radiation, convection and conduction, that should be entered in Scholander's equation. In general, it is about $300-400 \mathrm{Cal} . / \mathrm{m}^{2} / 24 \mathrm{~h}$ less than the observed heat production.

These observations do not alter the conclusions which follow from Scholander's studies. The critical temperature is determined, firstly by the heat production of the animal which is in turn determined by its food intake, and secondly by the total insulation of the animal. An animal can have a low critical temperature either because its nutritional status results in a high heat production under optimal conditions or because the conductance of heat through its skin and pelage is low. It follows that the suitability of a climatic environment depends on the nutritional level of the animal, a point well illustrated by the experiments of Lucas \& Calder $(1955 a, b)$ in which pigs were fattened at two nutritional levels in two environments.

Table I summarizes information relating to critical temperatures in adult farm livestock and man. The tissue conductance is highest for man and the clipped sheep and lowest for the heavily fleeced sheep. It should be appreciated that food shortages in outwintered stock by depressing heat production result in the stock having higher critical temperatures during winter than when food is plentiful. This difference is normally counteracted by the seasonal growth of the coat. However, coat growth is determined by the photoperiod and not by the environmental temperature rhythm (Yeates, 1955). Even so, it might appear from the table that the sheep immediately after shearing is the only species liable to direct climatic stress under British conditions. Such a conclusion, however, ignores components of climate other than air temperature. Wind velocity and the radiant temperature are important too, but so far no system of combining these measurements with air temperature to give an 'effective' (Houghten \& Yaglou, r923) or 'operative' (Gagge, I94I) temperature scale has been devised for different classes of stock. Natural environments may be much colder than air temperatures would suggest. Application 
Table I. Heat production of pigs, sheep, cattle and man, when fasting and when normally fed; estimates of the total conductance $(K)$ and ihe critical temperature, and comments based on supporting evidence

\begin{tabular}{|c|c|c|c|c|c|c|}
\hline Species & $\begin{array}{c}\text { Surface } \\
\text { area } \\
\left(\mathrm{m}^{2}\right)\end{array}$ & $\begin{array}{c}\text { Nutritional } \\
\text { level }\end{array}$ & $\begin{array}{l}\text { Heat production } \\
\text { in a } \\
\text { thermoneutral } \\
\text { environment } \\
\left(\mathrm{Cal} / \mathrm{m}^{2} / 24 \mathrm{~h}\right)\end{array}$ & $\begin{array}{c}\text { Total } \\
\text { conductance } \\
(\mathrm{K}) \\
\left(\mathrm{Cal} . / \mathrm{m}^{2} / 24 \mathrm{~h} /{ }^{\circ} \mathrm{C} .\right)\end{array}$ & $\begin{array}{c}\text { Computed* } \\
\text { critical } \\
\text { temperature } \\
\left({ }^{\circ} \mathrm{C} .\right)\end{array}$ & Comment \\
\hline Pig & $2 \cdot 0$ & $\begin{array}{l}\text { Fasting } \\
\text { Fattening }\end{array}$ & $\begin{array}{r}900\left({ }^{1}\right) \\
2000\left({ }^{(4)}\right)\end{array}$ & $\begin{array}{l}33^{3}-36\left(^{(1,2, a)}\right. \\
33^{-3}-36\end{array}$ & $\begin{array}{r}23 \\
-8\end{array}$ & $\begin{array}{l}\text { Capstick \& Wood (1) found the } \\
\text { critical temperature of fast- } \\
\text { ing to be } 2 \mathrm{I}^{\circ} \text {, and Irving et } \\
\text { al. }\left(^{3}\right) \text { found that fed pigs } \\
\text { could thrive in Alaska at } \\
\text { temperatures below o. }\end{array}$ \\
\hline Naked man & $1 \cdot 5$ & $\begin{array}{l}\text { Fasting } \\
\text { Normal activity }\end{array}$ & $\begin{array}{r}9000^{(5)} \\
20000^{(5)}\end{array}$ & $\begin{array}{l}\sim 80\left(^{(B)}\right. \\
\sim 80\end{array}$ & $\begin{array}{l}32 \\
19\end{array}$ & $\begin{array}{l}\text { The critical temperature of of } \\
\text { resting man with a heat } \\
\text { production of presumably } \\
\text { about I roo Cal.//m } / 24 \mathrm{~h} \text { is } \\
\text { usually placed at } 27^{2}-29^{\circ}\left(^{\circ}\right) \text {. }\end{array}$ \\
\hline $\begin{array}{l}\text { Sheep with } \\
\text { minimal fleece }\end{array}$ & $x \cdot 5$ & $\begin{array}{l}\text { Fasting } \\
\text { Maintenance } \\
\text { Fattening }\end{array}$ & $\begin{aligned} & 860(7) \\
\sim & 1500\left(^{9}\right. \\
\sim & 2500(8)\end{aligned}$ & $\begin{array}{l}80-83\left({ }^{8}\right) \\
80-83 \\
80-83\end{array}$ & $\begin{array}{l}32 \\
25 \\
13\end{array}$ & $\begin{array}{l}\text { Our experiments } 8 \text { show that } \\
\text { with underfed shorn sheep, } \\
\text { the critical temperature was } \\
\text { about } 38^{\circ} \text {. The remaining } \\
\text { estimates are consonant with } \\
\text { experimental results in this } \\
\text { laboratory. }\end{array}$ \\
\hline $\begin{array}{l}\text { Sheep with } \\
2 \cdot 5 \mathrm{~cm} \text { fleece }\end{array}$ & $1 \cdot 5$ & Maintenance & $\sim 1500\left({ }^{\circ}\right)$ & $43\left(^{10}\right)$ & 13 & $\begin{array}{l}\text { laboratory. } \\
\text { Studies in America }\left({ }^{14}\right) \text { with } \\
\text { sheep with heayy feeces also } \\
\text { show the critical tempera- } \\
\text { ture to be below } 0^{\circ} \text {. }\end{array}$ \\
\hline $\begin{array}{l}\text { Sheep with } \\
12 \cdot 0 \mathrm{~cm} \text { fleece }\end{array}$ & $I \cdot 5$ & Maintenance & $\sim 1500\left({ }^{8}\right)$ & $27\left({ }^{10}\right)$ & -4 & \\
\hline Cow & 45 & $\begin{array}{l}\text { Fasting } \\
\text { Maintenance } \\
\text { Full lactation }\end{array}$ & $\begin{array}{l}1000(11) \\
1750(12) \\
4000(11)\end{array}$ & $\begin{array}{l}\left.\sim 30{ }^{(19}\right) \\
\sim 3^{\circ} \\
\sim 3^{\circ}\end{array}$ & $\begin{array}{r}13 \\
-5 \\
-83\end{array}$ & 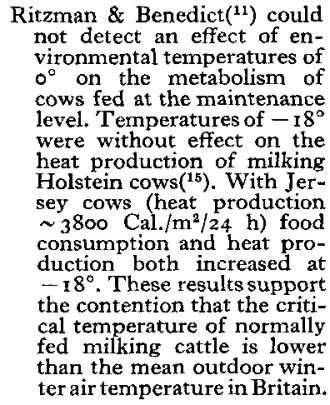 \\
\hline
\end{tabular}

*From the equation $T_{\mathrm{C}}=40--\quad \mathrm{K} \quad$. It is an approximation because it does not discount regional and general body cooling occurring at low environmental temperatures. Such cooling would be reflected in a lower value for the constant 40 . The constant $300 \mathrm{Cal} / / \mathrm{m}^{2} / 24 \mathrm{~h}$ may increase to more than $400 \mathrm{Cal} / / \mathrm{m}^{2} / 24 \mathrm{~h}$ with animals eating food and drinking water of low temperature.

(') Capstick \& Wood (Igz2).

(') Tangl (1912).

(3) Irving, Peyton \& Monson (r956).

(4) Breirem (x935, 1939); Mitchell \& Kelley (1938).

(5)A value of 3000 Cal. $/ 24 \mathrm{~h}$ has been taken (Lusk, 193 $\mathrm{T}$ )

(e)Du Bois (1936); Winslow \& Herrington (1949).

(7)Blaxter (1948).

( 8 Blaxter, Graham, Wainman \& Armstrong (1958).

(9) From observations incidental to other studies in this laboratory.

(10)Blaxter, Graham \& Wainman (I958).

(1) Ritzman \& Benedict ( 1938 ).

(12) Armsby (r9 r 7 ).

(12)Armsby (r9I7).

(14)Ritzman \& Benedict (I93 I)

(15)Worstell \& Brody (1953); Kibler \& Brody (r949).

of Bedford's (1946) method of climatic integration to pig houses (McLagan \& Thomson, 1950) presupposes that thermal reactions of the pig are the same as those of man, which may not be so. Again, rain can reduce coat insulation and remove heat from the animal by conduction as it drips from the animal or by vaporization from its wet skin. Conduction of heat to floors or soil much colder than the air is a further factor which would tend to increase the critical temperature. Social temperature regulation in groups of stock, e.g. in huddling pigs, makes it even more difficult to translate calorimetric experiments with individuals into practical terms. 
The above observations all apply to adult animals. The observations of Cairnie \& Pullar (1957) with baby pigs, ro days old, show that they have a critical temperature of $30^{\circ}$ and that it falls to $20^{\circ}$ by the time the piglets are 6 weeks old. Up to 6 days old, the baby pig does not appear to be thermoregulated efficiently, for its body temperature falls with falling environmental temperature (Holub, Forman \& Ježková, 1957; Pomeroy, 1953). Similar information is not available for lambs and calves, but in view of the small amount of subcutaneous fat in newborn sheep and cattle and the high immediate postnatal mortality of these animals in cold weather it might appear that they too are not well insulated against cold. The metabolic rate of the calf at birth is certainly lower than it is a week later, which would be a contributing factor (Roy, Huffman \& Reineke, I957).

\section{Calorie requirements below the critical temperature}

At temperatures below the critical temperature, heat production increases and less energy is stored, and in animals fed at maintenance level body fat is katabolized to provide energy (Young \& Cook, I955; Terroine \& Sorg-Matter, I928; Hart \& Heroux, 1956). The increase in energy requirement for a fall of $\mathrm{I}^{\circ}$ below the critical temperature is greatest for the animal with the poorest insulation. Experiments with sheep (Graham et al. 1958) show that protein metabolism is not increased under these conditions even though heat production is increased to about twice that obtaining during heavy fattening.

Below its critical temperature an animal loses identical amounts of heat per unit surface irrespective of its nutritional level. It follows that expressed on a surface basis, food has no specific dynamic action or heat increment at these temperatures. Distension of ruminant animals by indigestible feed residues, however, increases their effective surface area and tends to increase their heat losses at higher nutritional levels. Rations to be given below the critical temperature should therefore be high in metabolizable energy per unit bulk, and need contain minimal protein only. A high-fat diet would be ideal.

Appetite for food increases at low environmental temperatures. Thus baby pigs kept in unheated houses $\left(\sim 40^{\circ} \mathrm{F}\right.$ ) ate $37 \%$ more meal than those in heated houses $\left(\sim 60^{\circ} \mathrm{F}\right.$.) (Gill \& Thomson, 1956). Clearly a point must be reached as temperature falls below the critical temperature when an increase in appetite for a given ration no longer maintains the rate of growth. More concentrated rations must then be employed.

\section{Requirement of other nutrients}

Ershoff (I95I, I952) showed that the ability of rats to adjust themselves to low temperatures is impaired by deficiencies of pyridoxine and riboflavin. Similar results were obtained for thiamine by Hegsted \& McPhee (1950). Animals in cold conditions eat less of a deficient diet than of a normal one but gain less than those given a deficient diet at normal temperatures. Since these nutrients are required in proportion to the non-fat calories metabolized (Mitchell, I950) specific effects of vitamin deficiencies on acclimatization are difficult to interpret. There are few comparable 
or pertinent experiments with farm stock. Mitchell, Johnson, Hamilton \& Haines (1950), however, have shown that the riboflavin requirement of the pig is increased from $\mathrm{I} \cdot 2 \mathrm{mg} / \mathrm{kg}$ food at $85^{\circ} \mathrm{F}$. to $2 \cdot 3 \mathrm{mg} / \mathrm{kg}$ food at $42^{\circ} \mathrm{F}$. More food was consumed at the lower temperature, and the requirement of riboflavin/100 lb. body-weight was $1.4 \mathrm{mg}$ in the warm environment and $4.2 \mathrm{mg}$ in the cold. There is evidence too that requirements of calves for vitamin $A$ are increased under cold conditions (Keener, Bechdel, Guerrant \& Thorp, 1942).

At the Rowett Research Institute, it was shown that death associated with a degenerative liver disease in piglets aged 3-8 weeks occurred under cold damp conditions only and was prevented by warmth (Howie, Biggar, Thomson \& Cook, 1949; McLagan \& Thomson, I950; Naftalin \& Howie, I949; Shanks, I953; Lucas, I954). The suggestion has been made (Lucas, 1954) that this disease resembles toxic liver dystrophy of the pig, which can be produced experimentally if the ration is low in sulphur-containing amino-acids and vitamin $\mathrm{E}$ (Obel, 1953). In this regard, the incidence of clinical signs of enzootic muscular dystrophy, a disease of calves prevented by $\alpha$-tocopherol, increases in cold weather (Sharman, 1954) and hyaline defects of muscle fibres in otherwise normal calves appear to be associated with exposure to cold in the first days of life (Blaxter, Wood \& MacDonald, 1953).

These observations, though few, show that requirements for specific nutrients as well as for calories are increased in the cold. In general, however, the greatest direct effect of low temperature is on the calorie requirement.

\section{REFERENCES}

Allee, W. C., Emerson, A. E., Park, O., Park, T. \& Schmidt, K. P. (1949). Principles of Animal Ecology. Philadelphia and London: W. B. Saunders Co.

Armsby, H. P. (1917). The Nutrition of Farm Animals. New York: The Macmillan Co.

Bedford, T. (I 946). M.R.C. (War) Memor., no. I 7 .

Blaxter, K. L. (1948). F. agric. Sci. 38, 207.

Blaxter, K. L., Graham, N.McC. \& Wainman, F. W. (I 958). F. agric. Sci. (In the Press.)

Blaxter, K. L., Graham, N.McC., Wainman, F. W. \& Armstrong, D. G. (1958). F. agric. Sci. (In the Press.)

Blaxter, K. L., Wood, W. A. \& MacDonald, A. M. (1953). Brit. F. Nutr. 7, 34.

Breirem, K. (1935). Beretn. Forsøgslab. Kbh. no. 162.

Breirem, K. (I939). Tierernährung, II, 487 .

Burt, A. W. A. (1954-5). F. agric. Sci. 45, 389 .

Burton, A. C. (1934). F. Nutr. 7, $48 \mathrm{I}$.

Burton, A. C. \& Edholm, O. G. (1955). Man in a Cold Environment. London: Edward Arnold.

Cairnie, A. B. \& Pullar, J. D. (1957). F. Physiol. r39, isP.

Capstick, J. W. \& Wood, T. B. (1922). F. agric. Sci. 12, 257.

Du Bois, E. F. (1936). Basal Metabolism in Health \& Disease, 3rd ed. Philadelphia: Lea and Febiger.

Ershoff, B. H. (195I). Proc. Soc. Exp. Biol., N.Y., 78, 385.

Ershoff, B. H. (1952). Proc. Soc. Exp. Biol., N.Y., 79, 559.

Findlay, J. D. (1958). Proc. Nutr. Soc. 17, 186.

Forde, C. D. (1946). Habitat, Economy of Society, 5th ed. London: Methuen.

Gagge, A. P. (194I). In Temperature: Its Measurement and Control in Science and Industry, p. 544. [American Institute of Physics, editor.] New York: Reinhold Publishing Corp.

Gill, J. C. \& Thomson, W. (1956). F. agric. Sci. 47, 324.

Graham, N.McC., Wainman, F. W., Blaxter, K. L. \& Armstrong, D. G. (1958). F. agric. Sci. (In the Press.)

Hammel, H. T. (1955). Amer. F. Physiol. 182, 369.

Hammond, J. (1947). Biol. Rev. 22, 195.

Hart, J. S. \& Heroux, O. (1956). Canad. F. Biochem. Physiol. 34, 414.

Hegsted, D. M. \& McPhee, G. S. (1950). F. Nutr. 4r, 127. 
Herrington, L. P. (195I). Ann. N.Y. Acad. Sci. 53, 600.

Herrington, L. P. (1954). Met. Monogr. 2, 30 .

Holub, A., Forman, Z. \& Ježková, D. (1957). Nature, Lond., I8o, 858.

Houghten, F. C. \& Yaglou, C. P. (1923). Trans. Amer. Soc. Heat. Vent. Engrs, 29, $6_{3}$.

Howie, J. W., Biggar, W. A., Thomson, W. \& Cook, R. (1949). F. agric. Sci. 39, I 10.

Irving, L. \& Krog, J. (1954). F. appl. Physiol. 6, 667.

Irving, L., Peyton, L. J. \& Monson, M. (1956). J. appl. Physiol. 9, 421.

Keener, H. A., Bechdel, S. I., Guerrant, N. B. \& Thorp, W. T. S. (r942). F. Dairy Sci. 25,57 r.

Kibler, H. H. \& Brody, S. (1949). Res. Bull. Mo. agric. Exp. Sta. no. $45^{\circ}$.

Kirkwood, J. \& Smart, A. B. (1950). Bull. W. Scot. agric. Coll. no. 146.

Lucas, 1. A. M. (1954). F. agric. Sci. 44, 369 .

Lucas, I. A. M. \& Calder, A. F. C. (1955a). \%. agric. Sci. 46, 56.

Lucas, I. A. M. \& Calder, A. F. C. (1955b). F. agric. Sci. 46, $3 \circ 7$.

Lusk, G. (193I). The Elements of the Science of Nutrition. Philadelphia: W. B. Saunders Co.

McLagan, J. R. \& Thomson, W. (r950). F. agric. Sci. 40, 367.

Mitchell, H. H. (1950). Scientia, Bologna, 6th series, 44, 165.

Mitchell, H. H., Johnson, B. C., Hamilton, T. S. \& Haines, W. T. (1950). F. Nutr. 41, 3 :7.

Mitchell, H. H. \& Kelley, M. A. R. (1938). F. agric. Res. 56, 8 г .

Naftalin, J. M. \& Howie, J. W. (1949), F. Path. Bact. 6r, 3 I 9.

Obel, A. (1953). Acta path. microbiol. scand. Suppl. no. 94.

Pomeroy, R. W. (1953). F. agric. Sci. 43, I82.

Ritzman, E. G. \& Benedict, F. G. (193I). Tech. Bull. N. H. agric. Exp. Sta. no. 45.

Ritzman, E. G. \& Benedict, F. G. (1938). Publ. Carneg. Instn. no. 494.

Roy, J. H. B., Huffman, C. F. \& Reineke, E. P. (1957). Brit. F. Nutr. I1, 373.

Rubner, M. (1 902). Die Gesetze des Energieverbrauches bei die Ernährung. Leipzig u. Wien: F. Deuticke.

Sanders, H. G. (1927). F. agric. Sci. 17, 339.

Sanders, H. G. (1949). Proc. Brit. Soc. Animal Prod. Rep., I2th Mtg, p. 5.

Shanks, P. L. (1953). Vet. Rec. 65, 58.

Sharman, G. A. M. (1954). Vet. Rec. 66, 275.

Scholander, P. F., Hock, R., Walters, V. \& Irving, L. (I950). Biol. Bull. 99, 259.

Scholander, P. F., Hock, R., Walters, V., Johnson, F. \& Irving, L. (r950). Biol. Bull. 99, 317.

Scholander, P. F., Walters, V., Hock, R. \& Irving, L. (1950). Biol. Bull. 99, 225.

Tangl, F. (1912). Biochem. Z. 44, 252.

Terroine, E. F. \& Sorg-Matter, H. (1928). Arch. int. physiol. 30, 115.

Winslow, C. E. A. \& Herrington, L. P. (1949). Temperature and Human Life. Princetown: University Press.

Winslow, C. E. A., Herrington, L. P. \& Gagge, A. P. (1937). Amer. F. Physiol. r2o, 288.

Worstell, D. M. \& Brody, S. (1953). Res. Bull. Mo. agric. Exp. Sta. no. 5 I 5.

Wright, N. C. (1954). In Progress in the Physiology of Farm Animals, Vol. I, p. I91. [J. Hammond, editor.] London: Butterworths Scientific Publications.

Wulsin, F. R. (1949). In Physiology of Heat Regulation and the Science of Clothing, p. 3. [L. H. Newburgh, editor.] Philadelphia \& London: W. B. Saunders.

Yeates, N. T. M. (1955). Austral. F. agric. Res. 6, $89 \mathrm{I}$.

Young, D. R. \& Cook, S. F. (I955). Amer. F. Physiol. 18I, 72. 